\title{
Justyna SAMSEL
}

Uniwersytet w Białymstoku justyna_samsel@onet.pl

\section{ŚWIAT ZAPACHÓW W OPOWIADANIACH JAROSLAWA IWASZKIEWICZA}

\section{WSTĘP}

Opracowania dotyczące zjawisk związanych z odbieraniem zapachu jako „istotnego elementu społecznego funkcjonowania człowieka” (Buczkowski 2005: 77) jeszcze do niedawna były prawdziwą nowością. Podejmowanie badań nad percepcją węchową niewątpliwie związane jest z rozwojem wrażliwości na to, co dotyczy ludzkiego ciała ,jjako obiektu oglądu naukowego i rozwiniętego dyskursu moralnego" (tamże).

Anna Pajdzińska, analizując wrażenia zmysłowe jako podstawę metafor językowych, stwierdziła, że dla człowieka najważniejszy jest zmysł wzroku, następnie słuchu i dotyku, które są najczęściej przywoływane w wyrażeniach językowych. Najrzadziej metaforycznie konceptualizowane są zmysły smaku i zapachu (por. Pajdzińska 1996). W procesie poznania zmysłowi węchu przypadła więc stosunkowo skromna rola.

Przedmiotem niniejszego artykułu jest analiza słownictwa dotyczącego wrażeń zapachowych w prozie Jarosława Iwaszkiewicza. Zebrany przeze mnie materiał pochodzi z tekstów opowiadań (zob. Źródła). Celem tej analizy jest rekonstrukcja językowego obrazu wrażeń zapachowych w twórczości autora Panien z Wilka. Przez językowy obraz świata rozumiem, podobnie jak Ryszard Tokarski, „zbiór prawidłowości zawartych w kategorialnych związkach gramatycznych (fleksyjnych, słowotwórczych, składniowych) oraz w semantycznych strukturach leksyki, pokazujących swoiste dla danego języka sposoby widzenia poszczególnych składników świata oraz ogólniejsze rozumienie organizacji świata, panujących w nim hierarchii i akceptowanych przez społeczność językową 
wartości" (Tokarski 1993: 358). Świat zapachów w prozie Iwaszkiewicza traktuję jako istotne - choć subiektywne (podmiotowe) - wzbogacenie tak rozumianego, społecznie ustalonego, obrazu świata.

W przedstawionej niżej analizie opisów doznań zapachowych skupiam się na takich składnikach percepcji, jak: źródło zapachu, rodzaje doznań węchowych, sposoby percypowania i konceptualizowania wrażeń powonieniowych.

W słownikach języka polskiego węch definiowany jest jako 'zmysł powonienia; zdolność ludzi i zwierząt do odczuwania zapachów niektórych lotnych substancji rozproszonych w powietrzu (uwarunkowana pobudzeniem nerwów węchowych jamy nosowej przez cząsteczki tych substancji, dostające się wraz z powietrzem do nosa' (SJPSz). Hasło zapach w SJPDor jest określane następująco: 'odczuwana powonieniem właściwość ciał lotnych (lub substancji zawierających ciała lotne); woń'.

\section{2. ŹRÓDŁA DOZNAŃ WĘCHOWYCH}

W świetle badanego materiału językowego możemy stwierdzić, że źródłem zapachów są kwiaty i rośliny ozdobne występujące w ogrodach. Najczęściej pachną: róże (Nm: 7, 13; MnU: 277, 297, 298; PP: 766, 773), heliotropy (N: 188; PP: 766; KwII: 659), glicynie (HM: 631; PP: 773), oleandry (AG: 574, 584), maciejka (KzM: 216, 225, 299), bzy (Swk: 469; Sn: 806, 813), jaśminy (N: 245), kampanule (MnU: 277), lewkonie (PP: 773) i pelargonie (PP: 773). Niewiele jest wypowiedzeń, w których nie konkretyzuje się źródła woni (wymienia się tylko ogólną kategorię, na przykład „,kwiaty"): „przechadzaliśmy się ciemnymi, ciepłymi ulicami łowiąc powiewy wiatru niosące (...) od ogrodów Favority zapach kwiatów" (PP: 786). Odnalazłam natomiast przykład sytuacji percepcyjnej, w której pojawia się swoista profuzja woni, czyli obfitość, nadmiar zapachów: „Wszystkie kwiaty pachniały i wszystkie kwitły jednocześnie: liliowe judaszowe drzewa, glicynie, róże - i późne letnie lewkonie, podobne do małych drzewek, i czerwone pelargonie" (PP: 773).

Uwalnianie zapachu charakterystyczne jest także dla drzew. Językowe określenia woni drzew iglastych w prozie Jarosława Iwaszkiewicza wiążą się przede wszystkim z sosną ${ }^{1}$. Jej woń miesza się z zapachem ciała

1 Jak twierdzi Marian Bugajski, w literaturze polskiej woń drzewa iglastego zasadniczo łączy się tylko z sosną (por. Bugajski 2004: 167). 
przebywającej w sosnowym gaiku kobiety, o której mówi się: „Pachniała żywicą" (PzW: 76).

Igły sosnowe pachniały i krople, spadając z gałęzi i liści na zbutwiały dach werandy, stukały cicho (...) (B: 128).

Otaczała go woń sosnowych zwyczajnych mebli (...) (B: 105).

Wyjątkowo rzadko percypowany jest zapach świerku, dopełniony egzotyczną ingrediencją: „Stał teraz w oknie hotelu, pachnącego waniliową wonią świerkowych desek" (MnU: 313).

Oprócz wrażeń węchowych związanych z sosną i świerkiem pojawiają się wonie drzew liściastych, na przykład ściętego klonu: "Zapach świeżego do głębi zranionego drzewa przebijał się przez wilgoć" (N: 189). Obecne są też zapachy wierzby (AG: 546; N: 235) lub brzozy (Sn: 804). O zapachu wydzielanym przez brzozy wspomina się w opisie przyrody budzącej się do życia w porze wiosennej: „A potem znowu wiatr odwracał się i przynosił woń młodych listków brzozowych (...)” (Sn: 804). Najbardziej pachnącym drzewem liściastym, opisywanym $\mathrm{w}$ analizowanych opowiadaniach, jest jednak akacja. Świadczy o tym następująca deskrypcja: „Akacje były w pełnym kwiecie i ich gęsty przenikliwy zapach wisiał nad całym cmentarzem" (CwT: 348). Z kolei w charakterystyce zapachu lipy także podkreślona zostaje intensywność jej woni. Użycie rzeczownika alkohol uwypukla niezwykłość aromatu lipy. Alkohol konotuje ponadto takie cechy, jak 'przenikliwość' i 'ostrość'. Podobnie jak zapach alkoholu, woń lipy jest odurzająca: „Mocny zapach siana mieszał się z alkoholem lip, które kwitły, przekwitały raczej, gdzieś niedaleko" (MnU: 301).

Warto zwrócić uwagę, że pachnące drzewo egzotyczne jest reprezentowane w prozie Iwaszkiewicza tylko przez drzewo pomarańczowe: "Zapach duszący, odurzający zapach kwitnących pomarańczy owionął go i otoczył" (HM: 625-626). Należy jednak podkreślić, że zapach wydziela wyłącznie jedna część drzewa: kwiat pomarańczy (por. Bugajski 2004: 170): „A jednak w chłodnym powiewie wilgoci lekki zapach tych kwiatów przechodził smugami” (HM: 620). Hasło pomarańcza w SJPDor definiowane jest z uwzględnieniem zapachu kwiatów: 'Citrus sinesis, wiecznie zielone, niewysokie drzewo z rodziny rutowatych (Rutaceae) o białych, pachnących kwiatach i dużych, soczystych, jadalnych owocach; rośnie w strefie podzwrotnikowej i śródziemnomorskiej'. Podobna definicja pomarańczy z referencją do zapachu kwiatów widnieje w SJPSz. 
Osobną kategorię, poza opisami kwiatów i drzew, stanowią także trawy i zioła, wydzielające różnorakie wonie. Udział słownictwa olfaktorycznego w opisach tej kategorii roślin jest mniejszy niż w charakterystyce innych rodzajów flory. Obok zapachu piołunu (HM: 632; VdR: 609) mamy aromat mięty (HM: 632). W opowiadaniu Hotel Minerwa obecny jest ponadto zapach miodownika: „W trawie porastającej wnętrze zrujnowanej świątyni mocno pachniały piołuny i miodowniki" (HM: 630). Ustalenie konotacji związanych z wonią miodownika, wyeksponowaną w cytowanym opisie, może nastręczać pewnych trudności. Z pomocą przychodzi SJPSz, w którym czytamy, że miodownik to 'Melittis, roślina z rodziny wargowych, o kwiatach mających cytrynową woń'.

$\mathrm{W}$ analizowanych opowiadaniach zapach trawy nie jest szerzej charakteryzowany: „Trawy pachniały i mimo wesołej rozmowy było przeraźliwie smutno" (VdR: 611). W różnych kontekstach językowych pojawia się natomiast słownictwo odnoszące się do zapachu siana:

Zapach dobrego siana (...) przytłaczał po prostu w tym ciemnym miejscu (N: 216).

Tak, jakby lato już odchodziło, choć było obecne, dojrzałe pod ręką stojące, pełne zapachu siana i jagód (PzW: 90).

Był wrzesień, cała okolica Salzburga zbierała drugie (czy może trzecie już?) siano. Pachniało więc sianem (...) (MnU: 312).

Wyrażenie odurzający zapach siana konotuje takie cechy aromatu siana, jak 'mocny', świeży', a nawet 'upajający': „Powietrze jak nagrzane przeciągało uliczkami małej osady, niosąc odurzający zapach jesiennego siana" (MnU: 313).

Wyjątkowo licznie pojawiają się w twórczości Iwaszkiewicza opisy woni tataraku, przywołanego $\mathrm{w}$ tytule jednego $\mathrm{z}$ opowiadań:

Tatarskie ziele ma dwa zapachy. Jeżeli się potrze $w$ palcach zieloną jego wstążkę, miejscami przymarszczoną, poczuje się zapach, łagodną woń "wierzbami ocienionej wody", jak mówi Słowacki, trochę tylko zatrącającą wschodnim nardem. Ale kiedy się takie pasmo tataraku rozetrze, kiedy się włoży nos w bruzdę, wyłożoną jak gdyby watą, czuje się obok kadzidlanej woni zapach błotnistego iłu, gnijących rybich łusek, po prostu błota (T: 66).

Jak podkreśla Marian Bugajski, analizując ten opis, scharakteryzowana wyżej sytuacja percepcyjna koncentruje w sobie wszelkie doznania zmysłowe (Bugajski 2004: 164). Każda z dwu nazw: tatarskie ziele 
i tatarak wprowadza charakterystykę odrębnego zapachu (por. Pustkowski 2007). Percepcja obu zapachów odbywa się z włączeniem innych zmysłów: wzroku i dotyku. Jest to zgodne z sensualnym porządkiem w odbieraniu świata przez człowieka i hierarchią zmysłów. Na początku widzimy "zieloną wstążkę", następnie dotykając jej palcami, wyczuwamy, że miejscami jest „pomarszczona”, by w końcu poczuć przyjemną woń „wierzbami ocienionej wody" i odrobinę nardu. Dotyk połączony z wąchaniem i bezpośrednia obserwacja wzrokowa rośliny prowadzą do rozpoznania drugiego zapachu. Jest to "zapach błotnistego iłu, gnijących rybich łusek, po prostu błota" (T: 66).

Woń tataraku wielokrotnie w opowiadaniach powraca ${ }^{2}$. Nie odnalazłam jednak opisu, w którym związane $\mathrm{z}$ tą rośliną wrażenia węchowe miałyby pozytywny charakter. Jej nazwy zawsze konotują negatywne wartościowanie, np.: "Gałęzie w bocznych ołtarzach i snopy tataraku, pozostałe od Zielonych Świąt, pokurczyły się i wydawały dość przykrą woń schnących roślin" (MnU: 266).

Warto wspomnieć także o zapachu kadzidła, który jest charakterystyczny dla obrzędów religijnych i w takim kontekście pojawia się w opisach Iwaszkiewicza:

Lekki powiew od Apenin ochłodził trochę rozpalone powietrze, ale w kościele było duszno i zanadto pachniało kadzidłem (AG: 596).

Jakaś zakonnica grała na organach (...) i jej muzyka sączyła się razem z upałem i zapachem nazbyt ciężkim kadzidła do poruszonej mojej duszy (AG: 596-596).

W tradycji kulturowej woń kadzidła zajmuje poczesne miejsce wśród zapachów-symboli. Zapach kadzidła tradycyjnie kojarzy się modlitwą. Główny bohater opowiadania Anna Grazzi po wypadku samochodowym swojej ukochanej podąża do kościoła, by tam modlić się o jej powrót do zdrowia. W Świecie symboliki chrześcijańskiej czytamy, że woń kadzidła traktowana była jako nić umożliwiająca kontakt z bóstwem: „W ulatywaniu $\mathrm{w}$ górę i rozprzestrzenianiu się kłębów kadzidła widziano przejaw bóstwa, w woni - coś, co przynależy do jego istoty i jest uchwytne dla ludzi dzięki zmysłowi powonienia, a więc coś, co jest prawdziwą wonnością

2 Woń tataraku przywołana jest w opowiadaniu pod tym samym tytułem aż pięciokrotnie, pojawia się też w Mtynie nad Utratą, Młynie nad Kamionną oraz Straconej nocy. 
Boga. Kadzidło nie tylko miało być darem (...), lecz miało pomnażać siłę, która właściwa jest bóstwu i którą ono przekazuje ludziom. (...) Istotna jest jednak intencja $\mathrm{w}$ tej ofierze: ofiarowanie miłej woni, która cieszy bogów i czyni ich przychylnymi ludziom" (Forstner 1990: 218).

Zapach kadzidła automatycznie przywołuje na myśl skojarzenia z bezcielesną duszą, wywołuje asocjacje ze zmarłymi, konotuje tym samym 'krótkość życia' i 'przemijanie' (por. Kopaliński 1990: 78-79). Znamienny jest tu fakt, że bohater wspomnianego opowiadania percypuje zapach dymu kadzidlanego na krótko przed śmiercią żony:

(...) i jej muzyka sączyła się razem z upałem i zapachem nazbyt ciężkim kadzidła do poruszonej mojej duszy. I przynosiła spokój. W pewnej chwili uczułem nagle, jak gdyby urwało się wszystko we mnie, niepokój i żal, i strach; napełniała mnie wielka pewność i cisza. Zdawało mi się, że za moim ramieniem pochyliła się ku mnie postać wielkiej świętej i że mi szepnęła do ucha:

- Idź, prośba twoja jest wysłuchana. (...)

Poszedłem wprost do szpitala. (...)

- Umarła (AG: 596-596).

Zapach dymu kadzidlanego przybiera w utworze charakter znaku zapowiadającego interwencję sił irracjonalnych. Tworzy tym samym, w procesie percepcji, nastrój tajemniczości. Znajomość woni kadzidła ułatwia odbiór wrażeń węchowych związanych z wierzbą. Przymiotnik pieprzny profiluje element 'ostrości' w zapachu kadzidła, dzięki czemu zapach wierzb odbierany jest jako unikalny i aromatyczny: „Drzewa są już prawie rozwinięte i orszak starych wierzb nad wodą, okryty obłokiem wczesnej zieleni, pachnie mocno pieprznym zapachem kadzidła" (N: 235).

Opisywane w prozie Iwaszkiewicza polne przestrzenie często znamionuje obecność intensywnego zapachu koniczyny:

Koniczyny mocno pachniały, ćwierkały $\mathrm{w}$ nich świerszcze polne $\mathrm{w}$ niesłychanych ilościach (MnU: 294).

Cisza u stóp Kapitolu brzmiała brzękiem pszczół i cykad, duszącym zapachem białej koniczyny (VdR: 609).

Powyższe opisy dowodzą, że woń koniczyny odbierana jest jako nieprzyjemna. Duszacy zapach wyzwala konotacje 'ciężkości', 'odurzenia', 'oszołomienia'. Podobnie jak zapach koniczyny, woń łubinu jest niezwykle silna. Przymiotnik owocowy konotuje dodatnio wartościowane cechy zapa- 
chu: 'słodki', 'soczysty', 'przyjemny': „Łubiny kwitły i ich zapach prawie owocowy stał o zachodzie nad polami, dolatywał do ganku" (MnU: 265). $\mathrm{W}$ analizowanym przeze mnie materiale pojawiły się przykłady opisów zapachów ziemi:

Kiedyś wieczorem, już było ciemno, wracał z rozmokłego, czarnego i pachnącego pola (MnU: 319).

Pachniało rozmokłą ziemią i stwarzało to nastrój Wielkanocy jak u nas (AG: 544).

(...) teraz dopiero $\mathrm{w}$ zetknięciu $\mathrm{z}$ zimną ziemią i jej zapachem ogarnęło ja cierpienie prawdziwe i zaczęła szlochać (...) (MnL: 303).

Po zapachu ziemi poznała Elżbieta, że stoją nad wykopanym dołem (MnL: 302).

Marian Bugajski uważa, że "zapach ziemi jest w zasadzie wilgotny bądź też w jakiś sposób z wilgocią się łączy" (Bugajski 2004: 192). W badanych tekstach uwidacznia się podwójne wartościowanie zapachu ziemi. Dodatnia waloryzacja koreluje $\mathrm{z}$ mocą witalną ziemi, $\mathrm{z}$ wegetacją roślin oraz plonami. Ziemia symbolizuje macierzyństwo, płodność, a także dostatek związany z uprawą roli (Kopaliński 1990). Skojarzenia kulturowe łączą także matkę ziemię $\mathrm{z}$ miejscem grzebania zmarłych. Zapach ziemi w kontekście grobu będzie eksponował semantyczne cechy 'bólu', 'smutku', 'cierpienia' (zob. Tokarski 1998: 132).

Wyjątkowo rzadko w opowiadaniach pojawiają się nazwy zapachów „sztucznych”, czyli kosmetyków i perfum, np.: „Pod koniec przyszedł stary Grazzi starannie uczesany i pachnący wodą lawendową" (AG: 550).

Źródłem zapachów jest u Iwaszkiewicza także ludzkie ciało, które, jak twierdzi Krystyna Pisarkowa, „"powinno» być bezwonne, jego zapachu nie powinno się dostrzegać" (Pisarkowa 1972: 337). Jeśli się go wyczuwa, z reguły kwalifikowany jest jako nieprzyjemny, tak jak w następującym opisie: „W kościele stał tłum wiernych, grubych i cienkich, ale cuchnących ${ }^{3}$ porannym nieumyciem ludzi" (MnU: 290). W sytuacji, gdy subiekt jest zaangażowany uczuciowo w percypowanie zapachu, odbiera go w sposób subiektywny i wartościuje dodatnio:

3 W badanym materiale językowym brak przykładów użycia czasownika cuchnać. SJPDor znaczenie leksemu cuchnąć wyjaśnia następująco: 'wydawać przykrą, odrażającą woń; śmierdzieć'. Głębszą analizę określeń zapachów nieprzyjemnych w opowiadaniach Jarosława Iwaszkiewicza przeprowadzam w drugiej części artykułu. 
O zmroku Malwina kończyła robotę i pachniała ziemią i mydlinami (B: 150). [Tunia] Pachniała żywicą (PzW: 76).

Na górce pachniało teraz rezedą i wodą kolońską, świeżą bielizną, prześcieradłami, pudrem, jednym słowem: kobietami (PzW: 47).

W opisie leksyki związanej z wrażeniami węchowymi nie można pominąć kreacji zapachów powietrza w pomieszczeniach niewietrzonych, zamkniętych:

Gdy weszli do mieszkania wydało się Ignasi zawalone meblami, pachnące cygarami i nigdy nie przewietrzane (Swk: 417).

Na dworze było już ciepło, w pokoju panował półmrok i chłód kamiennej posadzki. Pachniało więdnącymi kwiatami i starymi książkami (AG: 506).

Warto zwrócić uwagę, że w analizowanych opowiadaniach źródło doznań zapachowych stanowi także, nacechowane pejoratywnie, słownictwo odnoszące się do choroby czy śmierci:

Zapach lekarstw i cisza pokrywająca wszystko, co się za tymi drzwiami działo, były nie do zniesienia (AG: 591).

(...) silny zapach kropli walerianowych panował w pokoju (PP: 779).

W zebranym materiale językowym brak natomiast nazw i określeń doznań olfaktorycznych związanych bezpośrednio z fizjologią ludzkiego ciała. Tego typu jednostki leksykalne nazywają odczucia negatywne, które budzą wstręt. W związku z tym unika się używania takich określeń ze względów obyczajowych i estetycznych, ponieważ są „zbyt dosadnie negatywne" (Pisarkowa 1972: 336), bądź łagodzi się negatywne wyrażenia, zastępując je eufemizmami.

\section{RODZAJE ZAPACHÓW, SPOSOBY ICH PERCYPOWANIA I KONCEPTUALIZOWANIA}

W obrębie leksyki dotyczącej wrażeń węchowych najliczniej eksploatowane $\mathrm{w}$ tekstach opowiadań Jarosława Iwaszkiewicza są wyrazy $z a$ pach i woń. Odnoszą się one zarówno do percepcji wrażeń przyjemnych, jak i nieprzyjemnych. Jolanta Lubocha-Kruglik zauważa, że „zjawisko afektywnego kategoryzowania zapachów na przyjemne i nieprzyjemne zależy najczęściej od upodobań indywidualnych" (Lubocha-Kruglik 2010: 168). Mirosława Michalska-Suchanek stwierdza natomiast, że 
doświadczanie zmysłowe wrażeń olfaktorycznych ,jest u większości ludzi - z uwagi na bezsprzeczne podobieństwo, a nawet identyczność działających bodźców węchowych (...), a także gatunkowe uwarunkowanie - w mniejszym lub większym stopniu zbliżone" (Michalska-Suchanek 1995: 528). Co więcej, jak sugeruje badaczka, w percepcji wrażeń zapachowych powszechnie występujące reakcje "przyjmują (...) w dużym stopniu charakter ponadindywidualny, stereotypowy" (tamże: 528-529). Oczywiście, owa "ponadindywidualność” w odbiorze zapachu nie sytuuje się na tym samym poziomie doznań, co uniwersalność percepcji barw czy dźwięków.

Czasownik pachnieć, czyli 'wydzielać woń, zapach (zwykle przyjemny), być pełnym przyjemnego zapachu' (SJPSz) łączy się najczęściej z określeniami zapachów przyjemnych. Wyjątkowo w badanych opowiadaniach predykat ten pełni funkcję eufemistyczną w połączeniu $\mathrm{z}$ nazwami zapachów nieprzyjemnych, na przykład:

Pachniało wapnem, kurzem, wystygłym kadzidłem, więdnącymi ziołami. Gałęzie w bocznych ołtarzach i snopy tataraku (...) wydawały dość przykrą woń schnących roślin. (MnU: 266).

Pachniało więc sianem i gnojówką, jaką polewano łąki, jak długo i szeroko (MnU: 312).

Leksem woń w badanej prozie eksploatowany jest rzadziej niż zapach. W większości analizowanych przykładów odnosi się do przyjemnego zapachu wydzielanego przez kwiaty:

Gdy pochylił się nad więdnącym kielichem nie poczuł już odurzenia. Za to woń w pokoju stawała się przenikliwsza (Nm: 13).

Woń kwiatów dolatywała ciężkimi pasmami z ogrodów położonych na tarasach wznoszących się ku górze, ponad domami miasteczka; kwitły róże i heliotropy (PP: 766).

Woń, podobnie jak zapach, zazwyczaj występuje w opisach zawierających pozytywne wartościowanie odbioru wrażeń węchowych. Okazjonalnie nazwa ta odnosi się do zapachu ocenianego negatywnie przez perceptora, tak jak w poniższym wypowiedzeniu: "Gałęzie w bocznych ołtarzach i snopy tataraku, pozostałe od Zielonych Świąt, pokurczyły się i wydawały dość przykrą woń schnących roślin" (MnU: 266). Przymiotnik wonny w znaczeniu 'mający, wydzielający przyjemny zapach; pełen przyjemnych zapachów, woni, nasycony zapachami' (SJPSz) nazywa przede wszystkim cechę roślin: 
(...) i wiatr, od czasu do czasu, potrząsał wonnymi kiściami liści w kształcie serca, błyszczącymi jak skóra (Sn: 813-814).

Podniosła zielone pasmo wodnej rośliny, którą upuściło przechodzące dziecko. Powąchała wonny liść (T: 84).

Nurkował, wypłynął na środek i po chwili znajdował się już w drugim końcu, gdzie rosły zielone pędy wonnej rośliny (T: 87).

Warto podkreślić, że u Iwaszkiewicza wonna jest także kawa: „Stali bez słowa w ciemnym pokoju, trzymając się za ręce, a jednocześnie pijąc po łyku wonnego płynu" (KwF: 707).

Synonimem nazw przyjemnego zapachu jest jednostka wyrazowa aromat, oznaczająca 'przyjemny zapach, miłą won' (SJPSz). Zazwyczaj leksem aromat i pokrewny mu przymiotnik aromatyczny $\mathrm{w}$ znaczeniu 'pełen zapachu, wydzielający przyjemny zapach; pachnący, wonny' (SJPSz) uczestniczą $\mathrm{w}$ kreowaniu obrazu zapachów percypowanych pozytywnie:

W tej chwili musnął ich głowy wiaterek, lekki i ciepły, idący od Viale dei Colli i niosący wątły i subtelny, przenikliwy aromat, jak gdyby gdzieś kwitły pomarańcze (KwF: 72).

Emanuel wlał kroplę aromatycznego koniaku do kawy i poinformował profesora o swej burzliwej nocy (...) (KwF: 691).

Możliwa jest jednak sytuacja percepcyjna, w której rzeczownik aromat współtworzy metaforyczne określenie zapachu śmierci. Wrażenie węchowe nazwane tu aromatem jest $\mathrm{w}$ istocie efektem procesu gnicia, który ewokuje tylko i wyłącznie woń nieprzyjemną: „do nozdrzy jej doleciał zapach błotnistego iłu, gnijących rybich łusek i woń błota - aromat śmierci, która miała się stać niebawem również jej udziałem (T: 92).

W zasobie słownictwa odnoszącego się do zapachów nieprzyjemnych w opowiadaniach Iwaszkiewicza odnalazłam czasownik śmierdzieć, którego zakres funkcjonowania sprowadza się do pojedynczego przykładu: „(...) zwłaszcza prześliczne były kury i świnie, choć koło jednych i drugich śmierdziało potężnie" (PzW: 63). W przykładzie tym znaczenie słownikowe leksemu śmierdzieć 'wydawać przykrą, odrażającą woń; cuchnąć' (SJPSz) zostało spotęgowane użyciem przymiotnika potężnie.

Nieprzyjemny zapach, określany mianem odoru, cechuje powietrze w pomieszczeniach osób chorych: „My z Felkiem baliśmy się tego powietrza, pełnego zapachu lekarstw i rozgrzanej blachy, zatłamszonego mocnym odorem tłustego pudru" (N: 191). Odór jest jednoznacznie definiowany i oznacza 'przykry zapach, nieprzyjemną woń, smród' (SJPDor). 
W opisach Iwaszkiewicza tak pojmowany odór charakterystyczny jest dla zwierząt: „Od obory szedł odór krowi i przyjemne zwierzęce ciepło, słyszało się przestępowanie bydląt z nogi na nogę" (N: 216). SJPDor dodaje, że odór oznacza 'dawniej (dziś wyjątkowo) w ogóle: zapach, woń'. W analizowanych opowiadaniach natrafiłam na jednostkowy przykład opisu, w którym leksem odór użyty jest synonimicznie w stosunku do zapachu w jego neutralnym znaczeniu: „Chodził główną ulicą tam i z powrotem, mając nozdrza pełne gęstych odorów górskiej jesieni" (MnU: 313).

Rzeczownikowym odpowiednikiem nazwy nieprzyjemnego zapachu, oprócz leksemu odór, jest jednostka wyrazowa zaduch. Zaduch rozumiany jako 'powietrze $\mathrm{w}$ zamkniętych pomieszczeniach pozbawione dostatecznej ilości tlenu, zepsute przykrymi woniami, przykry zapach' (SJPSz) znajduje w materiale egzemplifikacyjnym tylko jedno potwierdzenie: „Siedziałem przez chwilę jak przykuty, ale od wilgotnych cieniów pod drzewami, od zbutwiałych liści, od pokrzyw rozrosłych szedł zaduch ciężki w upalnym powietrzu" (CwT: 352). Jednostka leksykalna za$d u c h \mathrm{z}$ definicji suponuje negatywne wrażenia węchowe. Określenie ciężki uwydatnia pejoratywną ocenę zaduchu.

W grupie określeń zapachów nieprzyjemnych sytuuje się także leksem swąd. W SJPSz definiowany jest następująco: 'zapach spalenizny, dusząca woń, wydzielająca się z czegoś tlącego się, smażącego się; niemiła woń, odór'. W analizowanych konstrukcjach językowych natrafiłam tylko na jeden przykład z tym rzeczownikiem: „Eros smażyła specjalne racuchy na maszynce, swąd stał w obu pokojach nieludzki" (AG: 559).

Interesująco opisywane są sposoby rozprzestrzeniania się woni. $\mathrm{Z}$ badanego materiału wynika, iż leksemy woń, aromat, odór i zaduch łączą się $\mathrm{z}$ predykatami, które w swej semantyce zawierają komponent ruchu, na przykład:

Łubiny kwitły i ich zapach prawie owocowy stał o zachodzie nad polami, dolatywał do ganku (MnU: 265).

(...) lekki zapach tych kwiatów (pomarańczy - dop. J.S.) przechodził smugami (HM: 620).

(...) od zarośniętych skrętów drogi prowadzącej na plac Michała Anioła szedł gęsty jesienny, ale przejmujący roślinny aromat (KwF: 683).

Lekki zapach kadzideł unosił się w zimnym powietrzu (AG: 557).

Według Mariana Bugajskiego charakterystyczna dla zapachu metafora ruchu, wykorzystuje cztery fundamentalne dla polszczyzny nazwy 
ruchu: iść, jechać, lecieć i płynać (por. Bugajski 2004: 66). Ponadto, woń może pozostawać w bezruchu: "Akacje były w pełnym kwiecie i ich gęsty przenikliwy aromat wisiał nad całym cmentarzem" (CwT: 348).

Doznania olfaktoryczne są też wyrażane za pomocą metaforyki obrazującej ruch powietrza (tamże), jak w niżej cytowanych opisach:

Zapach duszący, odurzający zapach kwitnących pomarańczy owionął go i otoczył. Zrobił kilka kroków po kamiennych schodkach i wszedł w gąszcz nieokreślony, pachnący, szepcący (HM: 625-626).

Okrągłym ruchem podjazdu Wiktor Ruben wszedł przed ganek, przez ganek przeszedł; w przedpokoju owionął go zapach tego domu (PzW: 29).

W opowiadaniach Panny z Wilka i Hotel Minerwa pojawia się metafora "zapach owiewa”. Jej dynamiczny charakter podkreśla dokonany czasownik owionąć, czyli 'wiejąc ogarnąć, otoczyć kogoś lub coś' (SJPSz). Zapach konotuje tu cechy właściwe wiatrowi, a więc 'lekkość' czy 'delikatność': „Owionął go zapach tego domu” (PzW: 29), czyli otoczyła go woń przyjemna, przywołująca radosne doznania związane $\mathrm{z}$ pobytem $\mathrm{w}$ tym miejscu.

Należy pamiętać, że zapachy potrafią przywoływać wspomnienia. Edward Twitchell Hall twierdzi, że „(...) zapach wywołuje (...) wspomnienie znacznie głębsze niż obraz i dźwięk” (Hall 1978: 82). Na gruncie psychologii zjawisko to określa się jako efekt Prousta, który oznacza „unikatowość pamięci węchowej, jej odmienność od pamięci w zakresie innych modalności" (Czerniawska, Czerniawska-Far 2007: 93).

Rozprzestrzenianie się zapachu bywa konkretyzowane metaforycznie poprzez odniesienie do pojęcia wody, na przykład: „Zapach z daleka rozlewał się lekko i łagodnie i przenikał cały pokój" (Nm: 7).

Dość wyraziste w odniesieniu do wrażeń węchowych jest użycie metafory wroga. O tym, że woń może być pojmowana w kategorii nieprzyjaciela, świadczą przykłady użycia nazw, w których kontekście pojawiają się wyrażenia związane $\mathrm{z}$ walką:

Od wody uderzył w nozdrza Stefy zapach tataraków i przegniłych traw (MnK: 476).

Patrzył na ogród omyty z kurzu i na pobite róże i kampanule, które podnosiły głowę w miarę jak wysychały. Zapach bił z otwartego okna (MnU: 298).

Obrazowość metafory 'zapach to wróg' została w powyższym przykładzie podkreślona przenośnym użyciem czasownika uderzyć w odniesieniu do zapachu (oczywiście nieprzyjemnego). 
Niezwykle skąpo $\mathrm{w}$ badanej prozie reprezentowane są wyrażenia opisujące proces odbioru bodźców węchowych. $\mathrm{W}$ roli percypującego pojawia się najczęściej człowiek, rzadziej pies:

Picuś obwąchiwał drzewa, krzewy i kamienie (KzM: 201).

Wieś otoczyli dalekim kołem. Spała w zupełnej ciemności, tylko psy węszyły widać przechodzący pogrzeb, bo szczekały z daleka (MnL: 301).

Leksemy obwąchiwać i węszyć w znaczeniu percepcyjnym odnoszą się przede wszystkim do zwierząt. Predykat węszyć w SJPSz objaśniany jest następująco: 'o zwierzętach: węchem szukać czegoś, rozpoznawać coś; wciągać nozdrzami zapach czegoś, wietrzyć'. Obwąchiwać znaczy tyle co 'powąchać dookoła, ze wszystkich stron; zbadać węchem' (SJPSz). W obu definicjach wąchanie jest modelowane jako proces szukania i odbioru informacji nosem.

Bierny odbiór zapachu określany jest najczęściej za pomocą połączeń wyrazowych: wciagać w nozdrza (MnU: 329, BnrS: 24), wciagać nozdrzami (HM: 620, 630; KwII: 658), wciagać w płuca (HM: 632; N: 188), na przykład:

Usiedli nad brzegiem stawu, objąwszy się, i wciągali w nozdrza świeży zapach wilgoci i kwiatów, zapach wiosny (MnU: 329).

(...) i wciągaliśmy nozdrzami woń heliotropów, posadzonych po obu stronach ścieżek (KwII: 659).

(...) mocno pachniały piołuny i miodowniki. Rosalina wciągała cienkimi nozdrzami ten zapach wzmożony wieczorną rosą (HM: 630).

Użycie nazwy narządu powonienia w zwrocie wciagać zapach (woń) nie jest obligatoryjne, ale uwydatnia fakt, że percepcja węchowa towarzyszy oddychaniu (Grybosiowa 1989: 76). Jednocześnie implikowana jest informacja o istnieniu kanału (nosa, nozdrzy), którym percypujemy świat zapachów (tamże: 75). W konstrukcji z czasownikiem wdychać eksplicytnie wyrażony zostaje subiekt, który pasywnie percypuje zapach: „Stanął w otwartym oknie i wdychał pachnące, granatowe powietrze" (KwF: 689).

Wykorzystanie predykatu powachać, zgodnie ze znaczeniem słownikowym 'wciągnąć nosem zapach czegoś' (SJPSz), podkreśla celowość działań perceptora, co obrazuje opis: „Powąchała wonny liść. Przepadała za tym zapachem" (T: 84). Warto podkreślić, że czynna postawa percepcyjna u człowieka jest wyraźnie ograniczona czasowo. Krótkotrwałość odbioru bodźców węchowych oddaje prefiksacja po- przy predykacie powąchać (Grybosiowa 1989: 75). 
Ekwiwalentem czasownika wachać ${ }^{4}$ jest polisemantyczny czasownik czuć, który oznacza różne akty postrzegania zmysłowego (por. Termińska 1989). W badanych tekstach stosuje się nieosobową formę czuje się (poczuje się), która sprzyja obiektywizowaniu sytuacji percepcyjnej. Potwierdza to poniższy opis:

Tatarskie ziele ma dwa zapachy. Jeżeli się potrze w palcach zieloną jego wstążkę (...) poczuje się zapach, łagodną woń (...) trochę tylko zatracającą wschodnim nardem. Ale kiedy się takie pasmo tataraku rozetrze (...) czuje się obok kadzidlanej woni zapach błotnistego iłu, gnijących rybich łusek, po prostu błota (T: 66).

W przywołanym fragmencie inicjującym opowiadanie Tatarak nie pojawia się odniesienie do odbierającego zapach perceptora. Należy przypuszczać, że percepcja woni tataraku jest dostępna wszystkim obecnym $\mathrm{w}$ przestrzeni percepcyjnej.

\section{PODSUMOWANIE}

Z analizy zebranego materiału wynika, iż nazwy wrażeń węchowych $w$ tekstach opowiadań Jarosława Iwaszkiewicza da się podzielić zgodnie z tradycją klasyfikacyjną - na określenia zapachów przyjemnych i nieprzyjemnych. Należy jednak podkreślić, że podstawowym leksemem w opisie doznań pozytywnych lub negatywnych jest rzeczownik zapach, rzadziej woń. Najczęściej wskazywanymi w opisach źródłami zapachów są: kwiaty, drzewa, trawy, zioła, ziemia oraz ludzkie ciało. Konstrukcje językowe wykorzystują głównie predykat pachnieć jako nazwę zjawiska wydzielania zapachu. W odniesieniu do zapachów ocenianych negatywnie predykat ten zyskuje wartość eufemizmu. Badane teksty znamionuje niewielki udział słownictwa odnoszącego się do zapachów wybitnie nieprzyjemnych. Tylko w pojedynczych opisach pojawiają się leksemy zawierające $w$ swej semantyce komponent pejoratywnych doznań olfaktorycznych. Są to jednostki wyrazowe typu: śmierdzieć, cuchnacy, odór, zaduch, swąd. Mówiąc o określaniu zapachów nieprzyjemnych w prozie Iwaszkiewicza, należy podkreślić, że w tekstach opowiadań unika autor używania

\footnotetext{
$4 \mathrm{~W}$ analizowanej prozie nie odnalazłam przykładów użycia predykatu wąchać jako nazwy czynności wykonywanej przez osobę.
} 
takich rzeczowników jak smród czy fetor oraz słownictwa związanego z fizjologią człowieka. Jest to podyktowane normą obyczajową i względami estetycznymi.

Zebrany materiał egzemplifikacyjny wskazuje na dużą wrażliwość sensualną Jarosława Iwaszkiewicza. Prawie z każdego krajobrazu, opisywanego na kartach opowiadań, emanują przyjemne zapachy przyrody, które pozostają w opozycji do raczej nieprzyjemnych zapachów ludzi i zwierząt. Odbiór wrażeń węchowych determinuje działania perceptora, mające na celu wartościowanie zapachu i ustalenie jego źródła. Dzięki zmysłowi powonienia możliwe jest odbieranie zapachów, które budzą różnego rodzaju emocje czy przywołują wspomnienia. Umiejętność kategoryzowania bodźców węchowych zależy w dużej mierze od wiedzy językowej perceptora, ale przede wszystkim od wiedzy pozajęzykowej, z której wynika naturalna skłonność do charakteryzowania doznań powonieniowych poprzez odniesienia do innych wrażeń olfaktorycznych.

Zapach jako coś ulotnego, niewidocznego gołym okiem jest konkretyzowany za pomocą metafor pojęciowych: 'zapach to powietrze (wiatr)', 'zapach to ruch', 'zapach to woda' i 'zapach to wróg' (podobne schematy metafor wskazuje Bugajski 2004: 65-66). Z przedstawionego materiału językowego wynika, że odbiór wrażeń zapachowych odbywa się na dwa sposoby. Dominuje percepcja bierna, typowa dla człowieka. Wyrażają ją leksemy czuć i wdychać oraz związki wyrazowe, takie jak: wciagać w nozdrza, wciagać nozdrzami, wciagać w płuca. Jednostka wyrazowa powachać, używana $\mathrm{w}$ odniesieniu do osobowego perceptora, oddaje natomiast postawę czynną podmiotu. Wśród leksemów nazywających odbiór bodźców węchowych przez zwierzęta (psy) pojawiają się węszyć i obwąchiwać.

Przedstawione $\mathrm{w}$ tekście spostrzeżenia stanowią jedynie skromny zarys problematyki wrażeń zapachowych w prozie Jarosława Iwaszkiewicza. Obszerniejszą analizę językowego obrazu percepcji zmysłowej w twórczości tego pisarza będzie zawierała przygotowywana przeze mnie rozprawa doktorska.

\section{WYKAZ SKRÓTÓW}

SŁOWNIKI

SJPSz - Słownik jezzyka polskiego, t. 1-3, 1999, (red.), M. Szymczak, Warszawa SJPDor - Słownik języka polskiego, t. 1-11, 1958-1969, (red.), W. Doroszewski, Warszawa 


\section{ŹRÓDŁA}

Iwaszkiewicz J., 1969, Opowiadania zebrane, Warszawa, t. 1: Nowa miłość (Nm), Panny z Wilka (PzW), Brzezina (B), Nauczyciel (N), Młyn nad Utrata (MnU), Stońce w kuchni (Swk), Anna Grazzi (AG), Voci di Roma (VdR), Hotel Minerwa (HM), Koronki weneckie II (KwII), Kongres we Florencji $(\mathrm{KwF})$, Powrót Prozerpiny (PP), Stracona noc (Sn); t. 2: Bitwa na równinie Sedgemoor (BnrS), Mlyn nad Lutynia, Cmentarz w Toporowie (CwT), Młyn nad Kamionna (MnK); t. 3: Tatarak (T.), Kochankowie z Marony $(\mathrm{KzM})$.

\section{LITERATURA}

Buczkowski A., 2005, Społeczne tworzenie ciała. Płeć kulturowa i płeć biologiczna, Kraków.

Bugajski M., 2004, Jak pachnie rezeda. Lingwistyczne studium zapachów, Wrocław.

Czerniawska E., Czerniawska-Far J., 2007, Psychologia węchu i pamięci węchowej, Warszawa.

Forstner D., 1990, Świat symboliki chrześcijańskiej, przeł. W. Zakrzewski, P. Pachciarek, T. Turzyński, Warszawa.

Grybosiowa A., 1989, Opozycja homo $\|$ animal w polu wyrazowym percepcji wechowej, [w:] „Prace Naukowe Uniwersytetu Śląskiego w Katowicach. Prace Językoznawcze", t. 17: Studia historyczno-językowe, (red.) I. Bajerowa, Katowice, s. 71-81.

Hall E. T., 1978, Ukryty wymiar, przeł. T. Hołówka, Warszawa.

Lubocha-Kruglik J., 2010, Semantyczna kategoria perceptywności i jej wykładniki w języku polskim i rosyjskim, Katowice.

Kopaliński W., 1990, Stownik symboli, Warszawa.

Michalska-Suchanek M., 1995, Zapach jako kategoria poetyki. Na materiale opowiadań nowelistów rosyjskich lat osiemdziesiątych XIX wieku, „Slavia Orientalis", nr 4, s. $527-541$.

Pajdzińska A., 1996, Wrażenia zmysłowe jako podstawa metafor językowych, „Etnolingwistyka", t. 8, s. 113-130.

Pisarkowa K., 1972, Szkic pola semantycznego zapachów w polszczyźnie, „Język Polski", t. LII, s. 330-339.

Pustkowski H., 2007, „Tatarak” Jarosława Iwaszkiewicza (wprawka fitosemiotyczna), on line: http://portalliteracki.pl/artykul,34421,nested,0,0.html [dostęp: 11.05.2012 r.].

Termińska K., 1989, Rodzina wypowiedzeń konstytuowanych przez czasownik „czuć", [w:] „Prace Naukowe Uniwersytetu Śląskiego w Katowicach. Prace Językoznawcze", t. 16: Studia z językoznawstwa rosyjskiego i słowiańskiego, (red.) M. Blicharski, Katowice, s. 7-28. 
Tokarski R., 1998, „Biała brzoza, czarna ziemia”, czyli o miejscu stereotypu w opisie języka, [w:] Język a Kultura, t. 2: Stereotyp jako przedmiot lingwistyki. Teorie, metodologie, analizy empiryczne, (red.) J. Anusiewicz, J. Bartmiński, Wrocław, s. $124-134$.

Tokarski R., 1993, Słownictwo jako interpretacja świata, [w:] Encyklopedia kultury polskiej XX wieku. T. 2, Wrocław.

\section{THE WORLD OF SCENTS IN JAROSLAW IWASZKIEWICZ'S SHORT STORES}

\section{Summary}

The article is devoted to the analysis of vocabulary concerning aromatic sensations in Jarosław Iwaszkiewicz's short stories. Discussing the world of fragrance sensations of Brzeziny author, I focus on elements of perception as a source of scent, ways of scent reception, the perceptor's feelings and scent valuation by the experiencing subject. In the researched linguistic material, the most frequent sources of scent are: flowers, trees, grass, herbs, soil and human body. Within the lexis concerning olfactory sensations the most numerously exploited are word items scent and odor. Linguistic constructions use mainly a predicate to smell, which serves an euphemistic function with regard to unpleasant smells. The researched texts are characterized by an insignificant share of the vocabulary connotating pejorative evaluation of smell. The process of olfactory stimulants' reception occurs in two manners. A passive perception prevails that is typical of man. It results from the collected material that scent is concretized by means of notion metaphors: "scent is air (wind)", "scent is movement", "scent is water", and "scent is an enemy".

Key words: olfactory perception, scent, a linguistic image of the world, a metaphor, Jarosław Iwaszkiewicz 